\title{
Third world muscles in on climate treaty
}

\section{- Negotiations taken out of UNEP - Climate conference stumbles over details}

\section{Washington \& London}

WHILE 'disappointing' now seems to be the adjective of choice to describe this month's United Nations (UN) meeting on global climate, the gathering did reveal one potentially vital detail: with little fanfare, the balance of power in climate negotiations appears to be shifting towards the world's less-developed countries.

The key move came late last year when, in a little-noticed manoeuvre, a group of developing nations convinced the UN to move the climate treaty process out of the United Nations Environment Programme (UNEP) and into the UN General Assembly, where the developing nations have more influence. As a result, every step of the treaty negotiations, which are aimed at completing a draft treaty by 1992 , is now directly subject to General Assembly approval.

The long-term implications of the move are still open to debate, but to judge from the 10-day UN meeting (held 4-14 February in Chantilly, Virginia), it seems clear that the concerns of the developing nations have now risen near the top of the priority list. For instance, negotiations to create a travel fund for the developing nations consumed two full days of the meeting, which at times seemed more like a fund-raiser for developing countries than a climate convention. "It looked like a Jerry Lewis telethon", observed Alan Miller of the University of Maryland Center for Global Climate Change. "Denmark donated $\$ 100,000$ to the fund and everybody applauded."

With the process now firmly under the wing of the General Assembly, such scenes could become more rule than exception. In UNEP, influence is determined by political might and access to UNEP head Mustafa Tolba. But in the General Assembly, where the rule is one country, one vote, the developing nations believe that they can steer climate negotiations to address many of their own economic and cultural concerns. They argue that the industrialized nations, which are to blame for any global warming because of their unrestricted energy use, should not curtail the energy use of the rest of the world without providing financial aid and incentives to help the developing nations continue their growth.

"The Southern Hemisphere sees this UN move as an opportunity to extract something from the North", says Scott Hajost, an international lawyer with the
Environmental Defense Fund. With UNEP no longer in charge, the climate treaty process will now be monitored throughout by the full General Assembly, where the developing world enjoys a 10 to- 1 advantage. And that, the developing countries say, means that their voices can no longer be ignored.

If one manic example from the last day of the Chantilly meeting is any sign, they may be right. India led and nearly won a last-minute fight over a proposed fund to help developing countries to cut their carbon dioxide output. Facing off against the United States, India argued that a justapproved fund to encourage developing nations to reduce their use of ozonedestroying chemicals should be a precedent for any future carbon dioxide fund. Finally India gave in, but only so far as to table the point for a future meeting.

Some defend the shift away from UNEP, arguing that the issue of global climate change is bigger than both the UNEP and the World Meteorological Organization (WMO), the two groups that previously shared oversight of climate change. UNEP's past successes have been in such areas as ozone, hazardous waste and chemical exports - important issues, but insignificant compared with global warming. If global warming really is a problem on the order of war and famine, then it belongs on the main floor of the General Assembly with the rest of the world's crises, say the defenders of the shift from UNEP.

But others are concerned that global warming risks clumsy handling by the full UN body. "It's unlikely that the General Assembly is going to be the best place to debate climate diplomacy - as an institution it's too broad", Miller says. "In UNEP, global warming is the highest priority. But in the General Assembly, where does it rank?"

Furthermore, the move appears to be a significant setback for UNEP, which until this decision had been flying high on the success of its recent global ozone accords. And the damage may go even deeper. If the developing countries feel they can go to the General Assembly every time they feel slighted by UNEP, international climate diplomacy is in for a stormy future.

Although UNEP asked the Environmental Defense Fund to help it to lobby to have the climate process returned, the effort made little headway, even with US support. "The United States doesn't have a lot of allies right now",
Hajost says. "Even the Europeans basically caved in."

Beyond scuffling over travel funds and the like, the Chantilly meeting resolved only one key issue: delegates agreed to negotiate the treaty with two working groups. One, to focus on "substance", will address the mechanics of global warming, with emphasis on carbon "sources" and "sinks" - automobiles and forests, for example. The second working group, to address "procedures", will write the draft text of the treaty. But, in the spirit of the meeting, no committee chairs were named and no members appointed. That will have to wait for the next meeting, to be held in Nairobi in June.

Christopher Anderson \& Peter Aldhous

MANNED SPACEFLIGHT

\section{UK astronaut named}

\section{London}

The first Briton in space will be a woman. The food technologist Helen Sharman has been chosen in preference to Tim Mace, a major in the Army Air Corps, to fly on the Juno mission to the Soviet Mir space station in May.

Last summer, the chances of a British astronaut reaching Mir seemed remote,

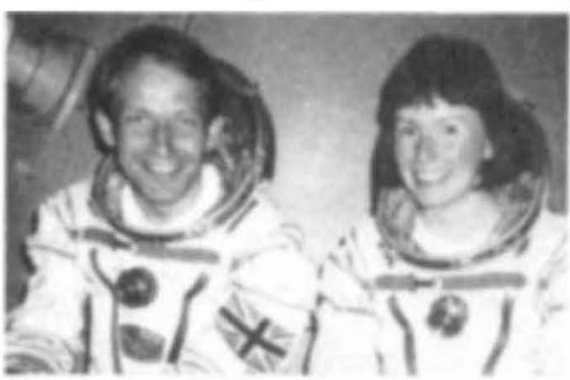

Mace and Sharman suited for space.

after commercial sponsors failed to come forward with funding for the mission. Juno's original financial backers, the London-based Moscow Narodny Bank, are now paying the Soviets an undisclosed sum to cover the flight, but one casualty has been the roster of British microgravity experiments that were to be included.

Juno's original science director, Heinz Wolff from Brunel University, dissociated himself from the mission in January, after his attempts to revive the British science programme failed.

Sharman will now spend about seven hours on each of the six days she is aboard Mir conducting experiments provided by NPO Energiya, the organization that builds launch vehicles for the Soviet space programme. These include tissue culture, plant growth experiments, and some work on human physiology under weightless conditions. Mace will continue training in the Soviet Union with a backup crew, should Sharman be forced to withdraw for any reason. Peter Aldhous 